\title{
IMPACT OF NATIONAL CULTURAL VALUES ON ORGANIZATIONAL CULTURE IN CONDITIONS OF MODERN MANAGERIAL PROCESSES
}

\author{
УТИЦАЈ НАЦИОНАЛНИХ КУЛТУРНИХ ВРИЈЕДНОСТИ \\ НА ОРГАНИЗАЦИОНУ КУЛТУРУ У УСЛОВИМА САВРЕМЕНИХ \\ МЕНАЏЕРСКИХ ПРОЦЕСА
}

\author{
Гордана Никчевић ${ }^{1}$ \\ Докторант на Економском факултету у Подгорици, \\ Универзитет Црне Горе
}

\begin{abstract}
Issues of the paper are focused on impact of national cultural values on organizational culture. The author first presents the basic guidelines of organizational and national culture, the most important typologies as well as some specificities of national and organizational culture's relationship in conditions of modern managerial processes. Further, for better understanding of the relationship of national and organizational culture, the author points to the connection between Geert Hofstede's dimensions of national culture and Charles Handy's types of organizational culture. In this context, due to various economic, political and social relations that are included in the global market, the author emphasizes the need for proper understanding of the complexity of the international environment and the importance of national culture on shaping business behavior and building organizational culture in conditions of modern managerial processes.
\end{abstract}

Key words: national culture, organizational culture, types of cultures, management

Сажетак: Проблематика рада усмјерена је на утицај националних културних вриједности на организациону културу. Аутор у раду, најприје, износи основне одреднице организационе и националне културе, типове организационе кулутре као и неке специифичности односа националне и организационе културе у условима савемених менацерских процеса. У раду се, ради бољег разумијевања односа националне $и$ организационе културе, указује на повезаност димензија националних култура Geerta Hofstedea и типова организационе културе Charlesa Handya. $У$ контексту тога, због различитих економских, политичких и друштвених односа који су укључени на глобалном тржишту, аутор истиче потребу правилног разумијевања сложености међународног окружења и значај националне културе на обликовање пословног понашања и изградњу организационе културе у условима савремених менаиерских процеса.

Кључне ријечи: национална култура, организациона култура, типови култура, менаимент

\footnotetext{
1 gogan@t-com.me
} 


\section{INTRODUCTION}

Today, in terms of globalization and major economic changes the culture is considered the basic characteristic of the nation. It conveys those characteristics to individuals, society and organization thus shaping a distinctive organizational culture. In recent decades, a trend of more intensive study of national culture and its impact on organizational culture has been highlighted. Namely, the necessity of organizations management in a changing environment leads to the abandonment of the old system of management, putting emphasize on the man as the strongest competitive asset of an organization. In the new business environment there is a need to introduce new cultural values and the companies' success increasingly depends on their adaptability and openness to the values, opinions and attitudes of various business partners. Under these conditions, the increasing importance has been given to research and understanding of various cultures as a basic prerequisite of a successful multinational business. However, analyzing the impact of cultural factor on organizations it can be noticed that the ratio between the national and organizational culture is much less studied in relation to other factors of companies (motivation, leadership, salaries). Therefore, the main objective of this paper is to point out the importance that national culture has in the process of organizational culture creation.

\section{CONCEPTUAL DEFINITION AND IMPORTANCE OF ORGANIZATIONAL CULTURE}

Organizational culture cannot be precisely defined because it is something that is perceived, felt and sensed. It is believed that there are as many definitions of organizational culture, as the authors who define it. Organizational culture is 'the collective programming of the mind which distinguishes the members of one human group from another. Within our cultures we have building blocks that consist of values, beliefs, norms and assumptions (Hofstede, 1983, p.46).

Organizational culture has its cognitive and symbolic component. Cognitive component consists of elements of managers and employees' interpretative schemes that the company imposes and through which affects not only the way they behave, but also the way they understand the world around them. Cognitive components of organizational culture are: assumptions, values, norms and attitudes (Žugaj et.al., 2004, p.13). The cognitive content of organizational culture is made of invisible elements of the culture itself. The symbolic components of organizational culture manifest cognitive elements of organizational culture and include 
Impact of national cultural values on organizational culture in conditions of modern managerial processes

everything that can be seen, heard and felt in the company. The symbols are made of all tangible and intangible objects and phenomena that occur as a result of employees' common assumptions, values and beliefs. These are: language, slang, stories, legends, rituals, way of dressing, external appearance of the building, etc. (Bouman, 2003, p.132 ).

Employees understand organizational culture based on what they see, hear and experience within the company. For a better understanding of organizational culture it is necessary to know its characteristics (Martin, 2002, p.37). Organizational culture has a social character, because it is created and expressed at the level of the group as a whole and not at the individual level. Organizational culture is a unique category, because it arose as a result of a common experience of all employees within the company. Building organizational culture is a long process, because a long period is needed for the creation of assumptions, values and beliefs that make up its content. In this sense, it is also a stable category, because a large part of its content is of subconscious character. It is important to point out that one characteristic can often be more emphasized than the other, so that it determines the characteristics of the company and the way of thinking in the company.

As a consequence of previous research in this area is important to note that organizational culture has achieved its legality, both in organizational theory and organizational research. Namely, the culture has become an accepted way of interpreting and monitoring the life of each company. Organizational culture affects all aspects of company's business. However, much more attention has been paid so far to the positive rather than the negative impacts. Better to say, negative impacts were generally ignored. The reason was to present organizational culture in the positive light which may also be counterproductive. Specifically, it is necessary to master the organizational culture to achieve through it positive and avoid negative impacts on business operations of the company.

The importance of organizational culture stems from the fact that it largely determines the meanings attached by the company's members to events and phenomena both within the company and out of the company. Such culture creates a solid unity among employees, which is based on the relationship of loyalty, belonging and commitment. The company builds its image on it and attracts more those ones who are satisfied by its values and beliefs. All of the above suggests that organizational culture has a great importance in the modern companies' operations and therefore on the society as a whole. 


\section{TYPES OF ORGANIZATIONAL CULTURES}

The interest in studying the impact of national culture on organizations, created as a result of the internationalization of business, gradually developed in North America and Western Europe after the Second World War. However, based on previously analyzed numerous studies devoted to this problem, it is considered that it is ,justifiable to tie the beginnings of studying the impact of culture on the organizations to the period of the sixties of the twentieth century, while in the seventies the awareness that serious analysis in this area cannot ignore the importance of cultural factors was prevailing" (Mojić, 2007, p.348).

Exploring organizational culture issues is driven, above all, by fast and strong development of Japanese companies. Since most of the authors who have studied the Japanese economy agreed that the organizational culture of Japanese companies is based on Japanese national culture, numerous researches of differences between national cultures intended to determine the intensity of impact of national culture on organizational culture followed (Janićijević, 1997, p.19).

In order to explain better the impact of national culture on organizational culture it is necessary to know the types of organizational culture. Knowing the types of organizational culture makes possible to identify the specific organizational culture. The greatest impact in researches has the classification that was first offered by Harrison and supplemented by Handy. In this sense, we distinguish between four types of culture: role culture, power culture, task culture and people culture (Janićijević, 1997, p.111-117).

Power culture is presented as a spider web and it is symbolized by the Greek god Zeus. Zeus symbolizes unlimited power of a man who creates all relations and behavior in the organization. In such cultures, everything is oriented towards the leader and everything depends on him. This culture is based on the assumption that the organization is a mean in the leader's hands to achieve certain objectives. The basic form of control is a personal supervision. Members of this culture tend to be intuitive and think generally. They do not analyze things too much, but think in a way that they see everything as a whole, that is see the complete picture and assess it as such. The leader and his vision are again responsible for every possible change in the company. The advantages of this type of culture are responsiveness and flexibility, and the lack is reflected in the fact that everything depends solely on the leader.

Role culture is a bureaucratic culture, because there is no leader, but what dominate are the rules and procedures. There is a unity of behavior and understandings, which are formed by the rules and 
Impact of national cultural values on organizational culture in conditions of modern managerial processes

procedures. This culture implies the organization as an organized social system. The control mechanism represents standardization of processes based on procedures and formal roles. Employees do only what is required and in a prescribed manner. Role culture has a resistance to changes. The power in this culture is acquired based on the hierarchical position or expert knowledge. The advantages of this culture are its reliability and efficiency. In the absence of initiative and entrepreneurship, they rather react slowly, which is their main disadvantage.

Achievement culture is represented by the Greek goddess Athena, and it is graphically represented by a spider web. It is characterized by success and results, independence of individuals and flexibility. In this culture, everything is directed and subordinated to solving tasks in the organization. There is no strict hierarchy and division of labor. People are not appreciated by the hierarchical position, but according to their expertise and ability to perform certain tasks. The basis of power is in the business expertise. Achievement culture is extremely versatile, since different groups and project teams that have been established for specific purposes are easily changed or dismissed. The main advantages of this culture are reflected in its orientation to success and results, flexibility, creativity and entrepreneurship. The disadvantages are the inability to use economy of scale and difficulties in controlling employees (i.e. overreliance on the ability of people).

Support culture is an individualistic culture. It is based on the assumption that the organization exists only to allow its members to achieve their individual goals and interests. Its graphic symbol is a set of individual stars that are casually related. The main feature of this culture is personal freedom of the individual. They can rarely be affected since they do not recognize the power of the organization, and consider themselves as the people who work for the organization and not in the organization.

When we talk about organizational culture it cannot be said in advance that culture is good or bad. It is important that a harmony between the culture and organization exists, i.e. that the culture corresponds to the type of organization and the way of doing things. It is also important to emphasize that the culture should not be an impediment for changes in an organization, because every organization changes over time. Therefore, it is desirable that the organization meets the requirements of the environment, changing the existing one and introducing new organizational culture. 


\section{NATIONAL CULTURE AND ITS IMPORTANCE FOR ORGANIZATION}

According to Hofstede "Culture is the collective programming of the mind distinguishing the members of one group or category of people from others" (Hofstede, 2001, p.9). In other words, national cultures are, according to Hofstede, "part of the mental software we acquire during the first ten years of our lives in the family, the living environment and at school, and they contain most of our basic values, while organizational culture is acquired when those values are already formed and when we enter a work organization as a young (or not-so-young) adults, with our values firmly in place and they consist mainly of the organization's practices" ( Jeknić, 2011, p.103-123).

The importance of national culture and its impact on organizations are highlighted by a number of authors who have dealt with this issue. National culture determines the values of organizational culture of companies that operate within its frameworks and significantly influence organizational culture. Certain authors point to existing differences between developed and developing countries (Pasa, Kabasakal, Bodur, 2001, p. 559). In this regard, developing countries are located in East and West Africa, Central and Latin America, the Middle East, in some parts of Eastern Europe and have certain common characteristics that differ in their intensity. They are characterized by underdeveloped infrastructure, low level of technological development, unskilled labor, political instability, etc. Furthermore, the developing countries can be identified as carrying low individualism, high uncertainty avoidance, low masculinity, high power distance and associative thinking.

Companies are today faced with multiple challenges. In order to be successful in working with people from other cultures, managers must be aware of cultural differences and similarities between their country of origin and the country in which they will operate. Companies need to provide a heterogeneous labor that belongs to different cultural and ethnic groups, to work together in achieving common goals. In order to achieve this, the organization must treat each individual with respect to all cultural diversities. Members of the organization carry in themselves certain values and beliefs that result from the impact of society to which they belong. This does not mean that all companies within a society will have the same organizational culture, but it is reasonable to expect that companies that were established and operate in the same society have the same or similar initial attitudes, assumptions and values. 
Impact of national cultural values on organizational culture in conditions of modern managerial processes

Based on the above it can be concluded that the lack of knowledge regarding national cultures and their impact on organizational culture can lead to serious problems and conflicts within the organization itself.

\section{DIMENSIONS OF NATIONAL CULTURES}

Numerous scientists, including a prominent Dutch scientist Geert Hofstede, have dealt with exploration of national culture dimensions. In the 70's of the last century Geert Hofstede conducted a very important survey on culture's impact on business, and the manners in which cultural differences may be overcame. How important is his model is represented by the fact from a comprehensive interdisciplinary, bibliographic database "Web of Science" that Hofstede's book "Culture's Consequences" was cited 5236 times in the period from 1980 to 2009 (Jeknić, 2011, p.112).

Dimensions of national culture of a society, according to Hofstede, are as follows:( Hofstede, 2001, p.98)

- Power distance - represents the extent to which people in the society accept inequality among people;

- Individualism and collectivism - represents the extent to which people in the society rather acts as individuals than groups' members;

- Femininity and masculinity - explains whether or not values like „masculinity” or „femininity” are preferred in the society;

- Uncertainty avoidance, to which Hofstede later added the fifth named:

- $\quad$ Confucian dynamism i.e. long-term and short-term orientation.

Power distance represents the extent to which the less powerful members of organizations and institutions in one country accept the fact that power is distributed unequally. Hierarchical relationships correspond to certain hierarchical levels that represent the embodiment of power in terms of oppression of the subordinates. If there is complexity of tasks within the organization multiple hierarchies is required with an appropriate division of labor and grouping of tasks. Power distance represents a qualitative experience of the span of management (span of control). It is measured between two adjacent hierarchical levels, so that the span of control is affected by: the environment, scope and complexity of the company's activities, planning development in business, training of subordinate staff, quality of communication, information, and the like. Span of control usually varies from level to level. In large organizations a limited span of control increases the number of levels in hierarchical structure.

Vol. 15, бpoj 3/2013, cmp. 157-170 
Power distance also determines the appropriate management styles. In high power distance organizations the supervisor neither shares power with his subordinates nor consults them in the decision making process. Managers are usually competent and determined to solve problems taking on all the risk and responsibility. High power distance cultures are Far East cultures, Latin American and Roman European cultures.

Low power distance organizations are characterized by involvement of employees in the formal decision-making process. The authority of managers is only valid in those areas related to their scope of work, and the subordinates are expected to have initiation, creativity and independence of thinking. Low power distance cultures are Anglo-Saxon, Germanic and Scandinavian cultures.

Individualism, that is collectivism, is the most researchable dimension. „Individualism relates to societies in which the ties between individuals are loose: everyone is expected to look after himself and his or her immediate family. Collectivism relates to societies in which people from birth onwards are integrated into strong, cohesive ingroups which throughout people's lifetime continue to protect them in exchange for unquestioning loyalty“ (Hofstede, 2001, p.225).

Individualism and collectivism are significantly different. Individualism starts from the assumption that there is a free will, so that they can change things and influence their own destiny. Management makes decisions independently and employees meet previously determined plan and do not have inclination for changes. Thus, the characteristic of individualistic cultures is the emphasis on individual initiative and achievement. Collectivism implies the existence of stronger social structure in which the group is responsible for the individual's destiny. The emphasis is given to the involvement of an individual in an organization where strong affiliation of that individual to the organization is felt. Furthermore, the characteristic of collectivist culture, which is contrary to the individualist culture, is the relationship between subordinates and superiors, which is defined in terms of moral obligations. The relationship and connection are more important than a task, and the management means managing the group. The decisionmaking process is based on consensus of the group, and workers are loyal to the working collective. This dimension proved to be an important one in motivation and recruitment of employees.

„Masculinity/Femininity" values relate to societies in which social gender roles are clearly distinct: men are supposed to be assertive, tough and focused on material success, women are supposed to be more modest, tender and concerned with quality of life (Hofstede, 2001, p.297). 
Impact of national cultural values on organizational culture in conditions of modern managerial processes

In masculine societies the following values dominate: aggression, achievement, acquisition of material goods. These are "to do cultures" in which one's value is proved by the result. In these cultures the values of an individual and his performance are assessed on the basis of earning money. In masculine societies a higher wage is preferred, "one lives to work." Organization dominated by masculine values tends to entrepreneurship, innovations and changes. These cultures manage determination and aggression. Masculine societies are Japanese, AngloSaxon and Latin-American.

Feminine national cultures are those dominated by values such as: relationships, quality of life, harmony, etc. These are the "culture's essences" in which the value of people is proved by existence itself. They favor social relations and the status in a society. The value of an individual is determined on the basis of his position in a social structure. Respect for other members of a group is more important than acquisition of material goods. These cultures start from the assumption that human life is predetermined and that the fate cannot be changed. In these cultures establishment of good connections and relations with social environment is preferred. In these cultures institution and consensus are managed. When it comes to working values, in feminine cultures more free time is preferred rather than more profit. The most distinctive feminine cultures are Scandinavian cultures, cultures of the Near and Far East and some Latin American cultures.

Uncertainty avoidance indicates ,to what extent a culture programs its members to feel either uncomfortable or comfortable in unstructured situations (Hofstede, 2001, p.161). In high uncertainty avoidance national cultures people do not like changes, risk and uncertainty. Formalization, standardization and hierarchy that should provide the society with stability and organization are preferred. Any forms of non-standard behavior are not desirable. These cultures prefer employment for a longer period of time so that organizations will change their employees less. They emphasize a large number of rules and regulations. In cultures of uncertainty avoidance low degree the real value is to work relaxedly. In these cultures one should work only when necessary because "hard work" is not considered a value. These cultures prefer working short period of time and employees in organizations are changed frequently. They also prefer fewer rules and regulations.

Long-term orientation versus short-term orientation refers to the extent to which culture influences its members to accept delayed meeting of their needs. Namely, ,long-term orientation represents the fostering of virtues oriented towards future rewards, in particular, perseverance and 
thrift. Its opposite, short-term orientation, represents the fostering of virtues related to past and present, concrete respect of tradition, „saving face"and fulfilling social obligations" (Hofstede, 2001, p.359). In contrast to the long-term orientation cultures that favor traits such as loyalty, responsibility, self-discipline and learning, short-term oriented cultures emphasize freedom, rights, independence and free time.

Regarding the above mentioned dimensions, Hofstede considers that power distance and uncertainty avoidance in particular affect our thinking about organizations. Power distance provides the answer to question ,who has the power to decide“, and uncertainty avoidance to question ,what rules or procedures will be followed to attain the desired ends in the organization". These two dimensions affect the planning and control processes in organizations. Namely, the more people in the hierarchy, the processes of planning and control are less formal, i.e. higher level of uncertainty avoidance requires detailed planning and control.

Hofstede believes that there are no universal principles of management and operations that could be equally applied to all organizations, but the principles are the result of different theories that have traits of those cultures in which they incurred." Each country or region has unique traits that no model can encompass" (Hofstede, 2001, p.370).

\section{RELATIONSHIP BETWEEN NATIONAL AND ORGANIZATIONAL CULTURE IN THE CONTEXT OF MODERN MANAGEMENT PROCESS}

Given that markets extend beyond the national boundaries, modern organizations may engage in those activities that enable them competitive advantage in the market. Every multinational company has its own culture, which is heavily influenced by national culture of the society in which it was created. Increase of multinational business involves increasing multiculturalism within the organizations themselves. Namely, due to development in modern technique and technology, organizations can locate their certain parts in the area that is most favorable to their business going beyond their national framework. Communication that takes place among members of different cultures requires from managers highly complex governance. Therefore, in order to develop a complex international environment and the specificities that derive from it, it is necessary to understand the complexity of national culture's influence on the shaping of business behavior and organizational culture building (Certo, Certo, 2008, p. 48). 
Impact of national cultural values on organizational culture in conditions of modern managerial processes

In practice, we can rarely have a situation in which one dimension of national culture dominates to such an extent to reduce or destroy the influence of other dimensions. Therefore, in examination of relationship between organizational and national culture, it is required to apply a holistic approach, where the national culture is observed as a system of assumptions, beliefs and values that are much more than a single cultural dimensions. This correlation is also confirmed by the fact that national culture is a source of organizational culture. Namely, employees in an organization are at the same time members of a certain national culture and carry the assumptions, values and beliefs in themselves. This, certainly, does not mean that organizational cultures of all organizations that operate within the borders of one country will be the same, but it is expected that in one national culture the dominant ones will be those types of organizational culture that are compatible with its basic dimensions. Also, the possibility for certain type of organizational culture which is not consistent with it by its values to appear in some national culture cannot be avoided. This is because the national culture is only one of factors of shaping and functioning of organizations. Therefore, cultural dimensions are just a prerequisite for creation of a certain type of organizational culture, since the influence of other factors in creation of organizational culture must be taken into account. However, there are certain discrepancies among a number of authors who have dealt with the relationship between national and organizational culture. Interesting is an attitude according to which organization cannot transform new employees into the specific culture of organization that departs from the society that surrounds it, but instead it adopts an organizational culture precisely with the values that are identical to the society that surrounds it (Ouchi, 1981, p.36-43). Organizations represent an open system, so it is understandable that there is a significant influence of the environment in which they operate. Thus, they adjust themselves to the environment, i.e. different cultural elements from the environment are introduced into organizations and affect their cultures (Trice, Beyer, 1993 p.147).

In contrast to previous perspectives that understand organization as an open system, there are thoughts that treat organization separately from social, i.e. cultural environment. They do not ignore the influence of national culture on organizational culture, but they emphasize general objectives set by organization management. This approach allows management to review the national culture in which the organization operates thus encouraging the creation of organizational culture that is aligned with the key assumptions of national culture (Adler, Jelinek, 1986, p. 74).

Vol. 15, бpoj 3/2013, cmp. 157-170 
The Hofstede model of cultural dimensions is important for understanding impact of cultural differences on shaping an appropriate management style and organizational culture. Namely, each of national culture dimensions encourages or hinders the occurrence of a certain type of organizational culture. If the society has a prominent cultural dimension of power distance, which means that power in the society is unevenly distributed, it implies development of power culture in organizations as well as unequal distribution of power within those organizations. The power that is in one society concentrated in the hands of an individual is reflected to organizations in this society. Uncertainty avoidance in a society, i.e. low level of risk acceptance, means acceptance of strict set of rules and procedures in the society and also in organizations that operate within it. In such a manner role culture is being developed with a strict formalization, standardization and a clear hierarchy (classic bureaucratic cultures). Organizational culture of the task fits cultural dimension of individualism that emphasizes individual characteristics of individuals (activism, initiative, entrepreneurship) in terms of tendency to focus individual efforts to the achievement of organization's objectives. If national culture is dominated by feminine values, a culture of support is developed in organizations. This includes emphasizing social relationships as more important in relation to the objectives of the organization.

The relationship between organizational and national culture can also be seen in the example of the so-called multinational companies. Namely, the communication between companies' organizational culture and specific national cultures is a very complex relationship. Given that those traits of organizational culture are those ones which made the company a success, the question is: to which extent are multinational companies actually willing to communicate with local (national) cultures?

Interdependence between organizational and national culture is usually considered unilaterally, in the sense that more studied in the literature are impacts of organizational culture on the organization than vice versa. Given that organizational culture permeates and connects all elements of the organization, it is difficult to determine the reverse influence of company's structure and its environment on organizational culture. This effect can be best seen through the relationship between organizational and national culture, i.e. organizational cultures must recognize main characteristics of national culture.

Cultural differences between certain societies are especially obvious when watching behavior of companies in the international environment. Therefore, any organizational decision cannot subsist permanently if behind that decision value and normative system of 
Impact of national cultural values on organizational culture in conditions of modern managerial processes

the society in which the organization lives does not stand (Zimanji, Štangl-Šušnjar, 2005, p. 294).

\section{CONCLUSION}

On the basis of the above it can be concluded that increasing number of companies and organizations that are characterized by certain specificities and characteristics that are product of national culture are present in the international market. The successful operation of global organizations requires knowledge of national, i.e. organizational cultures. If one ignores cultural values and norms of individual national cultures, business success and good results will fail.

Organizations in the world today have a very well-developed network of their branches through which they come in contact with the various national cultures. Therefore, global organizations pay more attention to organizational culture in their operations. Even though the national culture represents an important factor in the creation of organizational culture, characteristics of the industry, company's specific history as well as personality of the founders, i.e. leaders, etc. must not be overlooked. Therefore, a holistic approach where national culture as a system of assumptions, beliefs and values represents more than a set of individual cultural dimensions should be respected in relationship between national and organizational culture.

In this sense, the main recommendation would be that it is necessary to know the cultural characteristics of the environment in which companies operate and adjust organizational culture to these characteristics. In that context, managers should have a good knowledge of cultural values of those countries in which the business is conducted and develop a positive attitude towards the values of organizational culture that are different from those that are present in their environment. All this results in achieving compromise focused on the acceptance of common solutions for all members of different cultures who are involved in business relationships.

\section{LITERATURE}

1. Adler, N.J., Jelinek, M. (1986), Is Organization Culture Culture Bound?, Human Resource Management, 25(1), 73-90.

2. Bouman, K. (2003). Strategija u praksi, Novi Sad: Prometej.

3. Zimanji, V., Štangl-Šušnjar, G. (2005), Organizaciono ponašanje, Subotica: Ekonomski fakultet. 
4. Janićijević, N. (1997), Organizaciona kultura, Novi Sad: Ulix.

5. Jeknić, R. (2011), Kulture i organizacije: Organizacijske kulture Geerta Hofstedea, Zbornik 48(1), Split: Pravni fakultet.

6. Martin, J. (2002), Organizational Culture: Mapping the Terrain, London: Sage Publications.

7. Mojić, D. (2007), Organizacije i nacionalna kultura, Sociologija, XLIX (4), 347-351.

8. Ouchi, W.G. (1981), A Commentary on Japanese Management and Theory Organizations, Organizational Dynamics, 9(4), 36-43.

9. Pasa, S.F., Kabasakal, H.,Bodur, M. (2001), Society, Organisations, and Leadersip in Turkey, An International Review, 50(4), 559-589.

10. Trice, H.M., Beyer, J.M. (1993), The cultures of work organizations, Englewood Clifs New York: Prentice Hall.

11. Hofstede, G. (2001), Culture's Consequences: Comparing Values, Behaviors, Institutions, and Organizations Across Nations. Thousand Oaks, California: Sage Publications.

12. Hofstede, G.(1983), National Cultures in Four Dimensions, International Studies of Management and Organization,13 (2), 4674.

13. Certo, S.C., Certo, S.T. (2008), Moderni menadžment, Zagreb: Mate.

14. Žugaj, M., Bojanić-Glavica, B., Brčić, R., Šehanović, J. (2004), Organizacijska kultura, Varaždin: Tiva Tiskara. 